\title{
Valorización de fosfoyeso como material de construcción: aspectos radiológicos
}

\section{Valorisation of phosphogypsum as building material: radiological aspects}

\author{
H. Tayibi(*), C. Gascó(**), N. Navarro(**), A. López-Delgado(*), A. Álvarez(**), L. Yagüe(**), F. J. Alguacil(*), \\ F. A. López $\left.{ }^{*}\right)$
}

Recepción/Received: 26-III-10

Aceptación/Accepted: 8-VII-10

Publicado online/Published online: 03-XII-10

\section{RESUMEN}

Actualmente, en muchos países se está contemplando el uso alternativo del fosfoyeso (PG) en la industria de la construcción, aunque su contenido en radionucleidos naturales puede presentar ciertas restricciones para dicha aplicación (material clasificado por la US-EPA como TENORM: "Technologically Enhanced Naturally Occurring Materials). No obstante, estos inconvenientes podrían paliarse controlando el porcentaje del PG y los niveles de radioactividad en las materias primas a incorporar al cemento y calculando el índice de concentración de actividad (I) en los productos finales.

La valorización del PG como material de construcción se ha estudiado en este trabajo desde el punto de vista radiológico, desarrollando un nuevo proceso de estabilización/solidificación, obteniéndose un material de características similares al cemento y que presenta menor contenido de radionucleidos naturales que el PG inicial. Los niveles de $226 \mathrm{Ra}$ de este material $\left(26-27 \mathrm{~Bq} \cdot \mathrm{kg}^{-1}\right)$ son similares a los de algunos materiales de construcción utilizados comúnmente en España.

Palabras clave: fosfoyeso, radioactividad natural, TENORM, materiales de construcción, cemento de azufre.

\section{SUMMARY}

Nowadays, alternative uses of phosphogypsum (PG) in the building industry are being considered in several countries; however, the natural radioactivity level in the $P G$ could be a restriction for those uses. United States Environmental Protection Agency (US-EPA) classified PG as Technologically Enhanced Naturally Occurring Radioactive Material (TENORM). This drawback could be avoided controlling its percentage in the cement preparation and the radionuclides content in the other raw materials used in its production, and calculating the activity concentration index (I) in the final by-products.

The valorization of $P G$ as a building material has been studied, from a radiological point of view, by developing a new stabilisation/solidification process. $P G$ is incorporated within a polymeric sulphur matrix, obtaining a concretelike material, which presents lower natural radioactive content than the initial PG. The ${ }^{226}$ Ra content of this material ranged between 26-27 Bq. $\mathrm{kg}^{-1}$ and it is quite similar to that of common Spanish building materials.

Keywords: phosphogypsum, natural radioactivity, TENORM, building materials, sulphur concrete.

\footnotetext{
(*) Centro Nacional de Investigaciones Metalúrgicas (CSIC) (Madrid, España).

(**) Centro de Investigaciones Energéticas, Medioambientales y Tecnológicas (CIEMAT) (Madrid, España).
} 


\section{INTRODUCCIÓN}

El almacenamiento de residuos generados por las industrias denominadas "NORM" (Naturally Occurring Radioactive Material), en particular el fosfoyeso (PG), merece hoy día especial atención desde un punto de vista no sólo económico sino también medioambiental. Se hace necesario, por tanto, buscar usos alternativos sostenibles de estos residuos, teniendo en cuenta las limitaciones impuestas por las regulaciones y legislaciones tanto nacionales como internacionales.

En el caso del PG, el incremento de la demanda internacional de fertilizantes promueve la producción de grandes cantidades de este residuo en todo el mundo (100-280 Mt por año) (1). La mayor parte de estos residuos se almacenan en balsas sin ningún tratamiento previo, lo que representa una fuente potencial de una compleja contaminación ambiental. De una parte, las balsas que contienen el fosfoyeso ocupan grandes extensiones de terreno, en vez de ser empleados para otros posibles usos, y de otra, la emanación del radón proveniente del radio contenido en las balsas produce su incorporación a la atmósfera y el incremento de sus descendientes no volátiles de la cadena radiactiva $(210 \mathrm{~Pb}, 210 \mathrm{Bi}$ and $210 \mathrm{Po})$ en el entorno y en las aguas subterráneas. Esta contaminación se produce por filtración o contaminación directa del ecosistema acuático por el sobrenadante líquido procedente de las balsas de almacenamiento cuando se decanta el fosofoyeso de la fábrica de fertilizantes $(2,3)$. Aunque el PG consiste mayoritariamente en sulfato cálcico dihidratado, también contiene ácidos residuales, fluoruros, cierta cantidad de radionucleidos de origen natural y algunos metales pesados (4). Debido a su composición, el PG podría reemplazar a algunos componentes naturales de los materiales de construcción. Sin embargo, contiene una concentración de radiactividad más elevada que la mayoría de materiales empleados habitualmente en la construcción, tales como hormigón, ladrillos, piedras, etc. (Tabla 1) (5). Del contenido de radionucleidos naturales existente en la roca fosfatada, un $80 \%$ de ${ }^{226} \mathrm{Ra}$, un $90 \%$ de 210 Po y un $20 \%$ de $238 \mathrm{U}$ y $234 \mathrm{U}$, permanecen en el PG (6); siendo el ${ }^{226} \mathrm{Ra}$ la fuente principal de radiactividad en el PG (4). La Agencia Estadounidense de Protección Ambiental (US-EPA) (7) ha clasificado el PG como un material TENORM "Technologically Enhanced Naturally Occurring Radioactive Material".

La mayoría de los estudios referentes a las aplicaciones del PG muestran que este sub-producto se usa extensivamente en la obtención de cemento (8-10), paneles para paramentos y otros materiales de construcción (11-13) en Europa, Japón y Australia (14), mientras que en Estados Unidos se prohibió su uso desde 1992 (15) y la Agencia US-EPA restringe su uso en la mayoría de aplicaciones cuando la concentración de ${ }^{226} \mathrm{Ra}$ en

\section{INTRODUCTION}

The storage of the residues generated by "NORM" (Naturally Occurring Radioactive Material) industries, in particular phosphogypsum (PG), draws nowadays special attention from both economical and environmental point of view. This makes necessary to find sustainable alternative uses of these residues, taking into account the limitations imposed by the national and/or the international regulations and legislations.

In the case of $P G$, the enhancing international fertilizer demand promotes the production of a large quantity of this waste around the world (100-280 Mt per year) (1). Most of this quantity is habitually stock piled without any previous treatment, which represents a potential source of a complex environmental contamination. On the one hand, a large extension of land is occupied by stacks containing the $P G$, instead of being employed for other uses. On the other hand, the emanation of radon from the stacks produces its incorporation into the atmosphere and the increment of its non-volatile daughters $\left(210 \mathrm{~Pb},{ }^{210} \mathrm{Bi}\right.$ and $210 \mathrm{Po}$ ) in the surroundings areas and in the ground water. This last is produced by filtration or direct contamination of aquatic ecosystems by the liquid overflowing from the stacks when decanting $P G$ from the fertilizer factories $(2,3)$. Although $P G$ consists mainly of calcium sulfate dehydrate, also contains residual acids, fluorides, certain naturallyoccurring radionuclides and some heavy metals (4). Due to its composition, PG could replace some of the natural components of building materials. However, it contains a higher radioactivity concentration than the majority of commonly used products such as concretes, bricks, stones, etc (Table 1) (5). It is known that, $80 \%$ of ${ }^{226} \mathrm{Ra}$, $90 \%$ of $210 \mathrm{Po}$ and $20 \%$ of $238 \mathrm{U}$ and $234 \mathrm{U}$, originally present in the phosphate rock, remain in PG (6); being ${ }^{226} \mathrm{Ra}$ the most important source of $P G$ radioactivity (4). The United States Environmental Protection Agency (USEPA) (7) has classified PG as a "Technologically Enhanced Naturally Occurring Radioactive Material" (TENORM).

The majority of the reviewed studies on the $P G$ applications reported that this by-product has been used extensively in cement (8-10), wallboard and other building materials (11-13) in Europe, Japan and Australia (14), while in United States its use has been banned since 1992 (15) and the US-EPA ruling restricts PG exceeding $370 \mathrm{~Bq} . \mathrm{kg}^{-1}$ of ${ }^{226} \mathrm{Ra}$ from being used in most applications. Thus, the different uses of $P G$ depend 
Tabla 1 / Table 1

Concentraciones de actividad promedio y máximas de radionucleidos naturales en materiales de construcción comunes y subproductos industriales usados en los materiales de construcción en la UE (5). El índice de concentración de actividad (I) ha sido calculado e incorporado en la Tabla.

Average and maximum activity concentrations of naturally-occurring radionuclides in common buildings materials and industrial by-products used for building materials in the EU (5). The activity concentration index (I) was calculated and incorporated in the Table.

\begin{tabular}{|c|c|c|c|c|c|c|c|c|}
\hline \multirow[t]{2}{*}{ Material / Material } & \multicolumn{3}{|c|}{$\begin{array}{l}\text { Concentraciones de actividad pro- } \\
\text { medio (Bq. } \mathrm{Kg}^{-1} \text { ) / Average activity } \\
\left.\text { concentrations (Bq. } \mathrm{Kg}^{-1}\right)\end{array}$} & \multirow[t]{2}{*}{$\mathbf{I}$} & \multicolumn{3}{|c|}{ 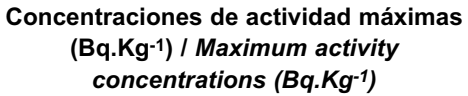 } & \multirow[t]{2}{*}{$\mathbf{I}$} \\
\hline & $226 \mathrm{Ra}$ & 232Th & ${ }^{40} \mathrm{~K}$ & & ${ }^{226} \mathrm{Ra}$ & 232Th & $40 \mathrm{~K}$ & \\
\hline Concreto / Concrete & 40 & 30 & 400 & 0.42 & 240 & 190 & 1600 & 2.28 \\
\hline $\begin{array}{c}\text { Concreto aireado y ligero / Aerated and } \\
\text { light-weight concrete }\end{array}$ & 60 & 40 & 430 & 0.54 & 2600 & 190 & 1600 & 10.15 \\
\hline $\begin{array}{l}\text { Ladrillos (rojos) de arcilla / } \\
\text { Clay (red) bricks }\end{array}$ & 50 & 50 & 670 & 0.64 & 200 & 200 & 2000 & 2.33 \\
\hline Ladrillos de arena-cal / Sand-lime bricks & 10 & 10 & 330 & 0.19 & 25 & 30 & 700 & 0.47 \\
\hline $\begin{array}{l}\text { Piedras de construcción naturales / } \\
\text { Natural building stones }\end{array}$ & 60 & 60 & 640 & 0.71 & 500 & 310 & 4000 & 4.55 \\
\hline Yeso natural / Natural gypsum & 10 & 10 & 80 & 0.11 & 70 & 100 & 200 & 0.80 \\
\hline Escoria del horno alto / Blast furnace slag & 270 & 70 & 240 & 1.33 & 2100 & 340 & 1000 & 9.03 \\
\hline Fosfoyeso / Phosphogypsum & 390 & 20 & 60 & 1.42 & 1100 & 160 & 300 & 4.57 \\
\hline
\end{tabular}

PG excede un valor de $370 \mathrm{~Bq} . \mathrm{kg}^{-1}$. De esta manera, los diferentes usos del PG dependen principalmente de su contenido en impurezas y radionucleidos de origen natural, así como de la disponibilidad de yeso natural de bajo coste y de la legislación vigente en cada país. En el caso de España, la utilización del PG sería una solución viable al problema ambiental generado por las fábricas de fertilizantes existentes en las proximidades de Huelva.

\subsection{Aspectos radiológicos relativos a la aplicación del fosfoyeso como material de construcción}

A pesar de la presencia en el PG de impurezas de distintos tipos que pueden afectar negativamente a la dureza y calidad del producto final, su aplicación en la obtención de materiales de construcción se considera como la mejor alternativa para el reciclado de este subproducto industrial, bien mediante la incorporación del PG al cemento o reemplazando al yeso natural. La aplicación previa de tratamientos químicos o térmicos permite minimizar los efectos adversos de los contaminantes existentes en el PG. No obstante, en los materiales que contienen PG es preciso considerar el riesgo radiológico asociado a la exposición en el interior de las viviendas, ya que como se ha mencionado previamente, el PG contiene cantidades relativamente grandes de radionucleidos pertenecientes a la serie natural encabezada por el 238U. En la Tabla 2, se muestra una comparación entre la concentración de radionucleidos naturales determinados en PG de diferentes países (4, 16-18). Los datos muestran que los niveles de $238 \mathrm{U}$ en todos los fosfoyesos strongly on the impurities and naturally-occurring radionuclides content, also on the availability of the lowcost natural gypsum and on the country and the governing rules. In the case of Spain, the utilization of PG would be a solution for the environmental problem created in the vicinity of Huelva fertilizer factories.

\subsection{Radiological aspects concerning phosphogypsum application as building material}

In spite of the presence of various impurities that can affect negatively the strength and the quality of the product, the building industry is being considered as the best alternative, either through the direct incorporation of the PG to the cement and/or by replacing the natural gypsum. Chemical and thermal treatment processes were previously applied to minimize the negative effects of the pollutants. However, radiological hazard due to indoor exposure must be considered for building materials containing $P G$. As mentioned above, $P G$ contains relatively high levels of $238 \mathrm{U}$-series radionuclides. A comparison between the radionuclides concentration determined in PG from different countries is illustrated in Table 2 (4, 16-18). Data shows that the levels of $238 \mathrm{U}$ in all PG sources were low and confirm that ${ }^{226} \mathrm{Ra}$ is the most important radioactivity source. Thus, the potential problem of $P G$ is found to be the emanation of $222 R n$ from the alpha-decay of ${ }^{226} R a$. The radon has an intense radiation capacity and a short half-life of 
son bajos y confirman que la principal contribución a la radioactividad del PG se debe al ${ }^{226}$ Ra. Por tanto, el problema potencial del PG se encuentra en la emanación del ${ }^{222} \mathrm{Rn}$ generado en la desintegración alfa del ${ }^{226} \mathrm{Ra}$. El radón tiene una vida media corta, de 3 a 8 días y una gran capacidad de producir elevadas dosis de radiación. Entre sus descendientes se encuentran emisores alfa como $218 \mathrm{Po},{ }^{214} \mathrm{Po}$ y $210 \mathrm{Po}$, de vida media muy corta $(0,2$ $\mathrm{ms}-26,8 \mathrm{~min}$ ) pero con una elevada capacidad de ionización, y por tanto de causar daño en órganos internos cuando se incorporan mediante inhalación, considerándose responsables de casos letales de cáncer (radionucleidos clasificados por la US-EPA como Grupo A de carcinógenos humanos). De esta forma, el uso de PG en los materiales de construcción podría producir un incremento de la dosis de radiación que recibirían los ocupantes de la vivienda construida a partir de este material (19), bien debido a la radiación gamma directa de los radionucleidos en cuestión o al efecto de sus descendientes.

La exposición a la radiación debido a la presencia de radionucleidos en los materiales de construcción y a concentraciones de radón, especialmente en espacios cerrados, está regulada por diferentes normas. A partir de 1990, la agencia US-EPA prohibió el empleo de PG en la mayoría de aplicaciones, incluyendo su uso en la construcción (15), en aquellos casos en los que el contenido de ${ }^{226} \mathrm{Ra}$ sea superior a 370 Bq. $\mathrm{kg}^{-1}$ En la Unión Europea, su uso ha sido discontinuo desde 1992. La mayoría de los países europeos aplican la recomendación que considera que la población no debería estar expuesta a dosis de radiación superiores a $0,7 \mathrm{mSv}$ procedente de los materiales de construcción; por lo tanto la dosis por radiación gamma total debida a ${ }^{40} \mathrm{~K},{ }^{226} \mathrm{Ra}$ y ${ }^{232} \mathrm{Th}$ no

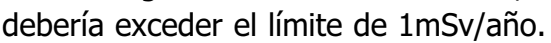

Este trabajo estudia la posibilidad de incorporar el PG en una matriz formada con azufre y un polímero de azufre con el objetivo de obtener un nuevo material (cemento modificado) para usos en ingeniería civil. La estimación del riesgo radiológico asociado al exceso de radiación gamma originada por este material requiere el cálculo
3-8 days. The most important of its progenies, such as alpha emitters $218 \mathrm{Po},{ }^{214} \mathrm{Po}$ and $210 \mathrm{Po}$ are short-lived (0.2 $\mathrm{ms}-26.8 \mathrm{~min})$, which causes significant damage to internal organs and consequently to be considered as a cause of lethal cancer cases (radionuclide classified by the US-EPA as a Group A human carcinogen). Thus, the use of $P G$ in building materials may lead to an increment to the radiation doses to the inhabitants (19) caused by the gamma emissions from each radionuclide itself or from its decay series.

Radiation exposure due to radionuclides in building materials and from radon concentrations, especially in closed space, is regulated by numerous standards. Since 1990, the US-EPA has completely prohibited the use of PG with a ${ }^{226} \mathrm{Ra}$ content which exceeds $370 \mathrm{~Bq} \cdot \mathrm{kg}^{-1}$ in most applications, including construction uses (15). In the European Union, this use was discontinued since 1992. The majority of the European countries apply the recommendation which considers that the population should not be exposed to more than $0.7 \mathrm{mSv}$ of radiation from building materials; therefore the total gamma radiation dose for radionuclides ${ }^{40} \mathrm{~K},{ }^{226} \mathrm{Ra}$ and ${ }^{232} \mathrm{Th}$ should not exceed the limit of $1 \mathrm{mSv} /$ year.

This paper discusses the possibility of incorporating PG within a polymeric sulphur matrix with the aim to obtain a new material for civil engineering uses. Assessment of the radiation hazard associated to the excess gamma radiation originating from this material requires the calculation of the external gamma radiation hazard

Tabla 2 / Table 2

Concentraciones de actividad de fosfoyesos de diferentes países (Bq. kg-1) $(4,16-18)$.

Activity concentrations of phosphogypsum from different countries $\left(B q . \mathrm{kg}^{-1}\right)(4,16-18)$.

\begin{tabular}{|c|c|c|c|c|c|}
\hline Origen & 238U & ${ }^{\mathbf{2 2 6} \mathbf{R a}}$ & 210Pb & 210Po & - \\
\hline España / Spain (16) & 220 & 670 & 520 & 80 \\
\hline China / China (17) & 15 & 85 & 480 & - \\
\hline Indonesia / Indonesia (16) & 43 & 473 & 490 & - \\
\hline India / India (17) & 60 & 510 & 323 & - \\
\hline Egipto / Egypt (18) & 140 & 459 & 1370 & - \\
\hline EE UU (4) & 130 & 1140 & - & - \\
\hline Australia / Australia (4) & 10 & 500 & - & - \\
\hline Suecia / Sweden (4) & 390 & 15 & - & - \\
\hline
\end{tabular}


del denominado índice de riesgo de la radiación gamma externa. En este trabajo, se ha calculado el índice de concentración de actividad (I) de acuerdo a lo propuesto por la Comisión Europea (20). Adicionalmente y a modo de comparación, se ha llevado a cabo una evaluación del contenido de radionucleidos de origen natural en algunos materiales de construcción empleados en el área de Madrid. Los valores calculados a partir de los datos de esta caracterización radiológica se han comparado con los obtenidos para el cemento modificado y la materia prima inicial empleada en su producción.

\section{MATERIALES Y MÉTODOS}

\subsection{Materiales y preparación de las muestras}

Las muestras de PG usadas en este estudio proceden de una fábrica de fertilizantes. Se han usado como aditivos, azufre granular tipo "Rubber Sul 10" con un tamaño de grano menor de $60 \mu \mathrm{m}$ procedente de las refinerías REPSOL IPF (Madrid, España) y un azufre modificado (conteniendo un polímero-STX ${ }^{\mathrm{TM}}$ ) proporcionado por Starcrete ${ }^{\mathrm{TM}}$ Technologies Inc. (Québec, Canadá). Con el objetivo de establecer el contenido de radionucleidos naturales en los materiales de construcción más comunes, se han utilizado como blancos dos tipos de escombros de materiales de construcción (mortero de cemento y ladrillos) procedentes de contenedores de obra localizados en el área metropolitana de Madrid.

Las muestras de fosfoyeso con polímero de azufre (SPC-PG), denominadas en este trabajo "cemento modificado", han sido preparadas usando un proceso de estabilización/solidificación (S/S) en el que se mezclan grava, con un tamaño de grano menor de $6,3 \mathrm{~mm}$, sílice, en una proporción del $0,43 \%$ (en peso), PG como relleno ( $10 \%$ sobre el peso total de la mezcla), azufre en dos diferentes porcentajes ( 15 y $17 \%$ ) y azufre modificado STXTM (10\% del contenido de azufre). La composición de las diferentes muestras de SPC-PG se muestra en la Tabla 3. Las muestras de SPC-PG se han obtenido de acuerdo con el procedimiento descrito por Vromm (21) y López et al. (22). La mezcla precalentada de grava, relleno y azufre se agitó en un mezclador IBERTEST Mod. 16-L005B alrededor de 30 minutos, hasta alcanzar una temperatura de $145^{\circ} \mathrm{C}$. A esta temperatura, a la que ya se encuentra index. In the present work, the activity concentration index (I) was calculated as proposed by the European Commission (20). An evaluation of the natural radioactive content in some common building materials used in a certain area of Spain, Madrid, was also carried out in this study. Derived values obtained from the radiological characterization of these materials were compared to those obtained for the modified cement and the initial raw materials used for its production.

\section{MATERIALS AND METHODS}

\subsection{Materials and sample preparation}

The PG samples used in this study came from a fertiliser factory. Granular sulphur type Rubber Sul 10 with a grain size of less than $60 \mu \mathrm{m}$ from REPSOL IPF refineries (Madrid, Spain) and modified sulphur (sulphurcontaining polymer) STX $X^{T M}$ supplied by Starcrete SM $^{T M}$ Technologies Inc. (Québec, Canada) were employed. In order to establish the content of naturally-occurring radionuclides in common building materials, two groups of rubble samples (cement mortar and bricks) from different building demolition containers located in the metropolitan area of Madrid were used as blanks.

Sulphur Polymer Concrete-PG samples (SPC-PG), named in this study as "modified cement", were prepared using a stabilisation/ solidification $(S / S)$ process by mixing gravel with a grain size of less than $6.3 \mathrm{~mm}$, silica sand in a proportion of $0.43 \mathrm{wt} \%, P G$ as filler (10\% of the mixture), sulphur in two different percentages (15 and $17 \%)$ and modified sulphur STXTM (10\% of the sulphur content). The composition of the different SPC-PG samples is shown in Table 3. The SPC-PG samples were manufactured according to the procedure described by Vromm (21) López et al. (22). The previously preheated mixture of gravel, filler and sulphur was stirred in an IBERTEST Mod. 16-LO05B mixer, for about 30 min until reaching $145{ }^{\circ} \mathrm{C}$. At this temperature the elemental sulphur was already molten and the modifier sulphur STX ${ }^{T M}$ was added. Temperature control is very important

Tabla 3 / Table 3

Composición de cementos modificados (SPC-PG), expresada en \% en peso.

Composition of the modified cement (SPC-PG) samples, expressed in wt\%.

\begin{tabular}{|c|c|c|c|c|c|}
\hline \multirow{2}{*}{ Muestra / Sample } & \multicolumn{5}{|c|}{ Componentes / Components } \\
\cline { 2 - 6 } & Grava / Gravel & Arena / Silica sand & PG & Azufre elemental / Elemental sulphur & STXMT \\
\hline SPC-PG15 & 25.0 & 50.1 & 8.4 & 15.0 & 1.5 \\
\hline SPC-PG17 & 24.4 & 48.8 & 8.1 & 17.0 & 1.7 \\
\hline
\end{tabular}


fundido el azufre elemental, se añade el azufre modificado STXTM. El control de la temperatura es esencial en esta etapa del proceso, ya que a temperaturas superiores a $150^{\circ} \mathrm{C}$ la viscosidad puede incrementarse rápidamente, lo que dificulta la manipulación y capacidad de trabajo de las muestras. Las mezclas se homogenizaron en el mezclador, se vertieron en moldes estándar precalentados (160 x 40 x 40 mm) (UNE 102031-99) (23) y se compactaron en una mesa vibradora a $3.000 \mathrm{rpm}$ durante 30-60 segundos (dependiendo de la viscosidad de la muestra). En la Figura 1 se comparan los monolitos obtenidos (SPC-PG15 y SPC-PG17). El contenido en azufre influye de manera importante en la manejabilidad y el amasado de la mezcla, de manera que las muestras con un contenido del $17 \%$ de azufre (SPC-PG17) fueron más fáciles de obtener que aquellas que tenían un $15 \%$. at this stage because at temperatures above $150^{\circ} \mathrm{C}$ the viscosity can increase rapidly, causing poor workability and handling of the mixtures. The mixtures were homogenised in the mixer and then poured into preheated standard moulds (160 × $40 \times 40 \mathrm{~mm}$ ) (UNE 102031-99) (23) and compacted by a vibrating table at $3000 \mathrm{rpm}$ for 30-60 seconds (depending on the sample viscosity). The comparative view of the obtained monoliths (SPC-PG15 and SPC-PG17) is illustrated in the Figure 1. The sulphur content has an influence on the workability of the mixture, thus the samples with $17 \%$ sulphur (SPC-PG17) showed better workability and aspect that those with $15 \%$.

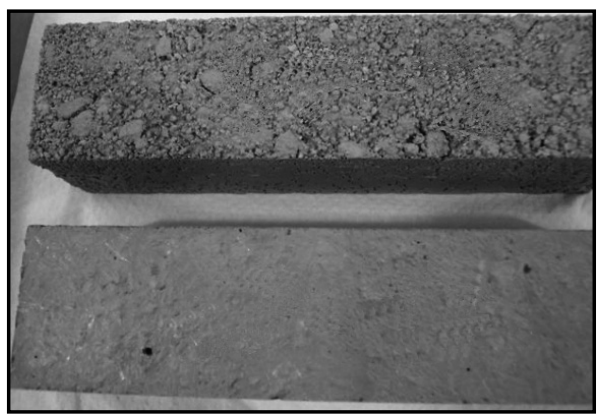

Figura 1. Aspecto macroscópico de las muestras de cemento modificado: SPC-PG-series. Figure 1. Macroscopic aspects of the modified cement samples: SPC-PG-series.

\subsection{Caracterización radiológica}

\section{Determinación del índice de concentración de actividad, I}

De acuerdo con la Comisión Europea (20), los materiales de construcción deberían ser considerados como exentos de todas las restricciones referentes a su contenido radiactivo si el exceso de radiación gamma que originan, da lugar a un incremento máximo de la dosis anual efectiva al ser humano de 0,3 mSv. Se recomienda también que el control sobre los materiales de construcción debería estar basado en un rango de dosis entre 0,3 a $1 \mathrm{mSv}^{-1}$. Este valor correspondería al incremento de dosis respecto al fondo radiactivo natural recibido como consecuencia del contenido radiactivo existente en los materiales de construcción. En la práctica, para controlar este incremento de dosis se establecen niveles de investigación en forma de un índice de concentración de actividad, I, ya que dicha dosis gamma es el resultado de la contribución de varios radionucleidos de origen natural presentes en los materiales de construcción. Este índice tiene también en cuenta las cantidades típicas y vías de utilización de los materiales de construcción en edificios y se calcula a partir de la siguiente fórmula [1]:

\subsection{Radiological characterization}

\section{Determination of the Activity Concentration Index, I}

According to the European Commission (20), building materials should be exempted from all restrictions concerning their radioactivity if the excess gamma radiation, originating from them, increases the annual effective dose of a member of the public by $0.3 \mathrm{mSv}$ at the most. It is also recommended that controls on building materials should be based on a dose in the range 0.3-1 mSv $\mathrm{y}^{-1}$. This is the excess gamma dose to that received outdoors. Investigation levels can be derived for practical monitoring purposes. Since more than one radionuclide contribute to the dose, it is practical to present investigation levels in the form of an activity concentration index. This index also takes into account typical ways and amounts in which the material is used in a building and is calculated from the following formula [1]: 


$$
I=\frac{C_{R a}}{300 \mathrm{Bqkg}^{-1}}+\frac{C_{T h}}{200 \mathrm{Bqkg}^{-1}}+\frac{C_{K}}{3000 \mathrm{Bqkg}^{-1}}
$$

Donde $\mathrm{C}_{\mathrm{Ra}}, \mathrm{C}_{\mathrm{Th}}, \mathrm{C}_{\mathrm{K}}$ son las concentraciones de actividad de ${ }^{226} \mathrm{Ra}$, ${ }^{232} \mathrm{Th}$ y ${ }^{40} \mathrm{~K}$, respectivamente en los materiales de construcción (Bq. $\mathrm{kg}^{-1}$ ). El valor de este índice no debería exceder los valores mostrados en la Tabla 4, que dependen del criterio de dosis seleccionado y de las vías de utilización y cantidades de material empleado en la edificación.
Where $C_{R a}, C_{T h}, C_{K}$ are the ${ }^{226} R a,{ }^{232} T h$ and ${ }^{40} K$ activity concentrations (Bq. $\left.\mathrm{kg}^{-1}\right)$ in the building material, respectively. The value of this index shall not exceed the values reported in Table 4, depending on the dose criterion and the way and the amount of the material used in a building.

Tabla 4 / Table 4

Valores del índice gamma recomendados por la Comisión Europea (RP-122, 1999) (20). Gamma-index values proposed by the European Commission (RP-122, 1999) (20).

\begin{tabular}{|c|c|c|}
\hline Criterio de dosis / Dose criterion & $0.3 \mathrm{mSv} \mathrm{a}^{-1} / 0.3 \mathrm{mSv}^{-1}$ & $1 \mathrm{mSv} \mathrm{a}^{-1} / 1 \mathrm{mSv}^{-1}$ \\
\hline $\begin{array}{c}\text { Material usado en grandes cantidades: ejemplo, hormigón / } \\
\text { Materials used in bulk amounts, e.g. concrete }\end{array}$ & $\mathrm{I} \leq 0.5$ & $\mathrm{I} \leq 1$ \\
\hline $\begin{array}{l}\text { Materiales superficiales y otros con uso restringido: azulejos, } \\
\text { tableros etc. / Superficial and other materials with restricted } \\
\text { use: tiles, boards, etc. }\end{array}$ & $\mathrm{I} \leq 2$ & $\mathrm{I} \leq 6$ \\
\hline
\end{tabular}

a: año / $y$ : year.

\section{Caracterización radiológica de algunos materiales de construcción}

La optimización de los niveles de radiactividad en el cemento cuando se incorpora el PG, requiere el conocimiento previo del contenido de radiactividad natural en los materiales de construcción comúnmente utilizados en España. Estos valores se compararán con los niveles de radiactividad del cemento modificado. Para ello se realizó un amplio muestreo en el que se recogieron más de 30 muestras de escombros de cada clase de material existentes en contenedores de obra localizados en el área metropolitana de Madrid. El análisis de la concentración de actividad de los radionucleidos naturales de interés ( ${ }^{226} \mathrm{Ra}$, ${ }^{232} \mathrm{Th}$ y ${ }^{40} \mathrm{~K}$ ) puede llevarse a cabo empleando diferentes técnicas analíticas. Generalmente, de todas las técnicas instrumentales posibles suele elegirse, la que resulta más rápida, barata y con menos manipulación de las muestras, en este caso la espectrometría gamma de alta resolución. La concentración de actividad de ${ }^{40} \mathrm{~K}$ se ha determinado por medio de su fotón gamma de $1460 \mathrm{keV}$, mientras que el ${ }^{232} \mathrm{Th}$ y ${ }^{226} \mathrm{Ra}$ se determinaron a través de las líneas de emisión de sus descendientes ${ }^{228} \mathrm{Ac}$ y ${ }^{214} \mathrm{Bi}$, respectivamente. Antes de su medida, las muestras se molieron, se homogeneizaron y se colocaron en contenedores de polietileno "tipo Marinelli" que fueron sellados y almacenados durante 28 días hasta alcanzar el equilibrio radiactivo. ${ }^{226} \mathrm{Ra}$ y ${ }^{232} \mathrm{Th}$, ambos emisores alfa, podrían haber sido determinados también mediante espectrometría alfa, pero esta técnica de medida requiere mayores tiempos de análisis debido al

\section{Radiological characterization of some building materials}

The optimization of the radioactive levels in the cement, when $P G$ is incorporated, requires the previous knowledge of the natural radioactive content in common building materials used in Spain. These values will be compared to the levels of the "modified cement". For that, a wide sampling was performed to collect more than thirty rubble samples of each kind of material from containers located in Madrid metropolitan area. The analysis of the activity concentration of naturallyoccurring radionuclides (226 Ra, ${ }^{232} \mathrm{Th}$ and ${ }^{40} \mathrm{~K}$ ) can be performed with several radiochemical techniques. Generally, one selects the most rapid, cheaper and less handling procedure. High resolution gamma spectrometry was selected in this case; $40 \mathrm{~K}$ was measured directly by its $1460 \mathrm{keV}$ gamma photon, whereas ${ }^{232} \mathrm{Th}$ and ${ }^{226} \mathrm{Ra}$ were determined through gamma emission lines of their daughter products, ${ }^{228} \mathrm{AC}$ and ${ }^{214} \mathrm{Bi}$, respectively. Prior to their measurement, samples were crushed, homogenized and placed in polyethylene beakers, which were completely sealed for 28 days until radioactive equilibrium was reached. Alpha spectrometry could be also used for ${ }^{226} \mathrm{Ra}$ and $232 \mathrm{Th}$ analysis (both of them alpha emitters) but it is a timeconsuming technique and the sample representativeness is lower than in gamma spectrometry, due to the quantity of sample used for the analysis (1-2 $g$ (alpha spectrometry) versus 50-500 g (gamma spectrometry)). Population means and standard deviations for each radionuclide $\left({ }^{226} \mathrm{Ra},{ }^{232} \mathrm{Th}\right.$ and $\left.{ }^{40} \mathrm{~K}\right)$ and kind of material, 
necesario pretratamiento químico de las muestras. Adicionalmente, la representatividad de la muestra es menor que la proporcionada por la espectrometría gamma, debido a la cantidad de muestra que requieren ambas técnicas el análisis mediante esta técnica requiere (1-2 g (espectrometría alfa) versus $50-500 \mathrm{~g}$ (espectrometría gamma)). A partir de los datos obtenidos en la caracterización radiológica se han obtenido las distribuciones de probabilidad de cada radionucleido $\left({ }^{226} \mathrm{Ra},{ }^{232} \mathrm{Th}\right.$ et $\left.{ }^{40} \mathrm{~K}\right)$ y sus parámetros característicos: media y desviación estándar, así como el índice de concentración de actividad (I). Estos análisis se realizaron en el laboratorio del Servicio de Protección Radiológica del CIEMAT y los valores obtenidos pueden ser considerados como niveles de fondo radiactivo de los materiales de construcción.

\section{Caracterización radiológica del fosfoyeso y de las materias primas}

Las mismas técnicas de medida mencionadas en el apartado anterior se han utilizado para la caracterización del PG, materias primas iniciales y el cemento modificado. Además del ${ }^{226} \mathrm{Ra}$, ${ }^{232} \mathrm{Th}$ y ${ }^{40} \mathrm{~K}$, se determinaron los radionucleidos $210 \mathrm{Po}$ y $210 \mathrm{~Pb}$ (hijo/padre), descendientes del ${ }^{220} \mathrm{Rn}$, ya que el $210 \mathrm{Po}$ debería ser controlado en la producción industrial del cemento modificado. Este radionucleido es sólido en condiciones normales de presión y temperatura, pero se puede volatilizar, dependiendo de la forma química, a la temperatura de preparación del cemento. La determinación del $210 \mathrm{~Pb}$ permite verificar el equilibrio radiactivo de la cadena de desintegración del uranio al mismo tiempo que corregir la concentración del polonio radiactivo.

La concentración de actividad del $210 \mathrm{~Pb}$ se ha determinado por espectrometría alfa (24). Para ello, alícuotas de $1 \mathrm{~g}$ de PG y cemento modificado se disolvieron mediante digestión húmeda en placa calefactora a temperatura controlada $\left(<90^{\circ} \mathrm{C}\right)$. En la digestión de las muestra de PG se empleó como reactivo $\mathrm{HNO}_{3} 8 \mathrm{M}$, mientras que para las muestras de cemento modificado se empleó una mezcla de $\mathrm{HNO}_{3} / \mathrm{HF} / \mathrm{HCl}$. Antes de iniciar la digestión húmeda, se añadió a las muestras una alícuota de una disolución patrón de ${ }^{209}$ Po con actividad certificada, para determinar el rendimiento químico del proceso. Los isótopos de polonio se auto-depositaron en discos de plata pura de $2,5 \mathrm{~cm}$ de diámetro siguiendo el método de Flynn (24). El $210 \mathrm{~Pb}$ se determinó mediante espectrometría gamma usando un detector de $\mathrm{Ge}$ ultra-puro, de tipo-p y geometría coaxial, a través de su línea de emisión de 46,5 KeV. Las medidas se llevaron a cabo en la misma geometría usada para el análisis de ${ }^{226} \mathrm{Ra},{ }^{232} \mathrm{Th}$ y ${ }^{40} \mathrm{~K}$. as well as the activity concentration index (I), were calculated. These analyses were carried out at the laboratory of the Radiation Protection Service at CIEMAT and the obtained values can be considered as a radioactive background level.

\section{Radiological characterization of phosphogypsum and raw materials}

The same measurement techniques mentioned above were used for the radiological characterization of $P G$, the initial raw materials and the modified cement. Besides ${ }^{226} \mathrm{Ra},{ }^{232} \mathrm{Th}$ and ${ }^{40} \mathrm{~K}$, the parent-daughter pair $210 \mathrm{Po}$ and $210 \mathrm{~Pb}$, descendants of ${ }^{220} \mathrm{Rn}$, were determined since $210 \mathrm{Po}$ should be controlled in the modified cement industrial production. This radionuclide is solid under normal temperature and pressure conditions, but could be volatilized under certain chemical forms and cement preparation temperature. The $210 \mathrm{~Pb}$ determination allows to verify the radioactive equilibrium in the uranium decay chain as the same time as polonium activity concentration is corrected.

$210 \mathrm{~Pb}$ activity concentration was determined by alpha spectrometry (24). $1 \mathrm{~g}$ aliquots of $P G$ and modified cement were acid digested onto a hot plate at a controlled temperature $\left(<90^{\circ} \mathrm{C}\right) .8 \mathrm{~mol} \cdot \mathrm{l}^{-1} \mathrm{HNO}_{3}$ was used for $\mathrm{PG}$ samples and a mixture of $\mathrm{HNO}_{3} / \mathrm{HF} / \mathrm{HCl}$ was added in the case of the modified cement samples. ${ }^{209} \mathrm{Po}$ certified dissolution was added as a tracer to estimate the recovery of the whole process. The polonium isotopes were auto-deposited in silver disks following the Flynn's method (24). 210Pb was analyzed by gamma spectrometry using a coaxial ultra-pure p-type germanium detector (HPGe) through its $46.5 \mathrm{KeV}$ gamma emission line. Measurements were carried out in the same geometry used for the analysis of ${ }^{226} \mathrm{Ra},{ }^{232} \mathrm{Th}$ and ${ }^{40} \mathrm{~K}$. 


\section{RESULTADOS Y DISCUSIÓN}

Las Figuras 2 y 3 muestran la distribución de frecuencias del contenido de ${ }^{214} \mathrm{Bi}\left({ }^{226} \mathrm{Ra}\right),{ }^{228} \mathrm{Ac}(232 \mathrm{Th})$ y ${ }^{40} \mathrm{~K}$ en las muestras de ladrillos y morteros, respectivamente, como ejemplo de los niveles de concentración de actividad en los materiales de construcción más comúnmente utilizados. Los valores obtenido se pueden considerar como niveles de fondo radiactivo y las relaciones ${ }^{234} \mathrm{Th} / 214 \mathrm{Bi}$ (Figura 4) como indicadores del grado de equilibrio de los radionucleidos naturales de la serie del uranio. La posible ruptura de este equilibrio se produce por la formación del gas noble ${ }^{220} \mathrm{Rn}$, existente entre los productos de desintegración de esta serie radiactiva. La no existencia de equilibrio radiactivo entre el ${ }^{226} \mathrm{Ra}$ y sus descendientes indicaría que el índice de concentración de actividad no podría ser aplicado como nivel de investigación y que deberían realizarse cálculos adicionales.

\section{RESULTS AND DISCUSSION}

Figures 2 and 3 show the frequency distributions for ${ }^{214} \mathrm{Bi}\left({ }^{226} \mathrm{Ra}\right),{ }^{228} \mathrm{Ac}\left({ }^{232} \mathrm{Th}\right)$ and ${ }^{40} \mathrm{~K}$ in bricks and cement mortar samples, respectively, as an example of the activity concentration levels for common building materials. The obtained values can be considered as a radioactive background level, and the ratio ${ }^{234} \mathrm{Th} / 214 \mathrm{Bi}$ (Figure 4) could be used as an indicator of the equilibrium in the natural uranium radioactive series. Breakdown of the radioactive equilibrium is originated by the presence of a noble gas, $220 R n$, existing among the decay products of this radioactive series. The nonexistence of radioactive equilibrium among ${ }^{226} R a$ and its descendants would indicate that the activity concentration index can not be applied as investigation level and therefore, further calculation should be necessary.

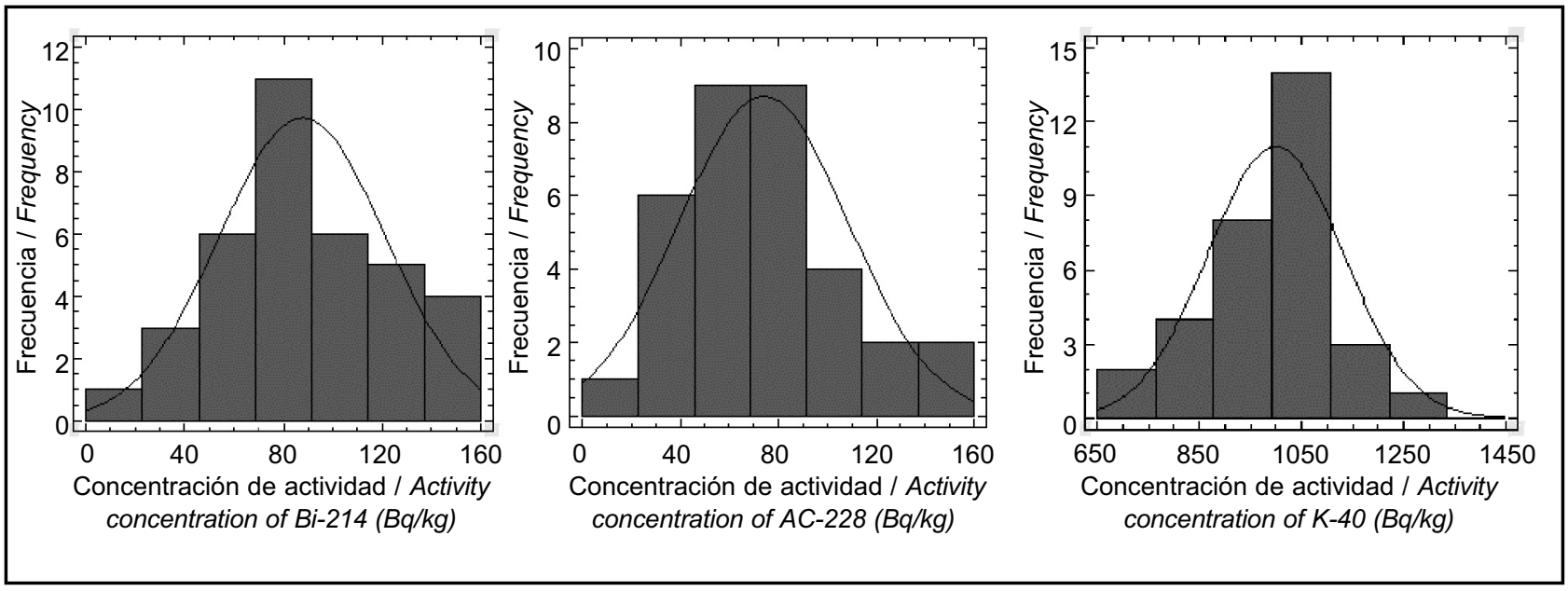

Figura 2. Distribuciones de probabilidad de ${ }^{214} \mathrm{Bi}\left({ }^{226} \mathrm{Ra}\right),{ }^{228} \mathrm{Ac}(232 \mathrm{Th})$ y ${ }^{40} \mathrm{~K}$ en las muestras de ladrillos. Figure 2. Frequency distributions of ${ }^{214} \mathrm{Bi}(226 \mathrm{Ra}),{ }^{228} \mathrm{Ac}(232 \mathrm{Th})$ and ${ }^{40} \mathrm{~K}$ in brick samples.
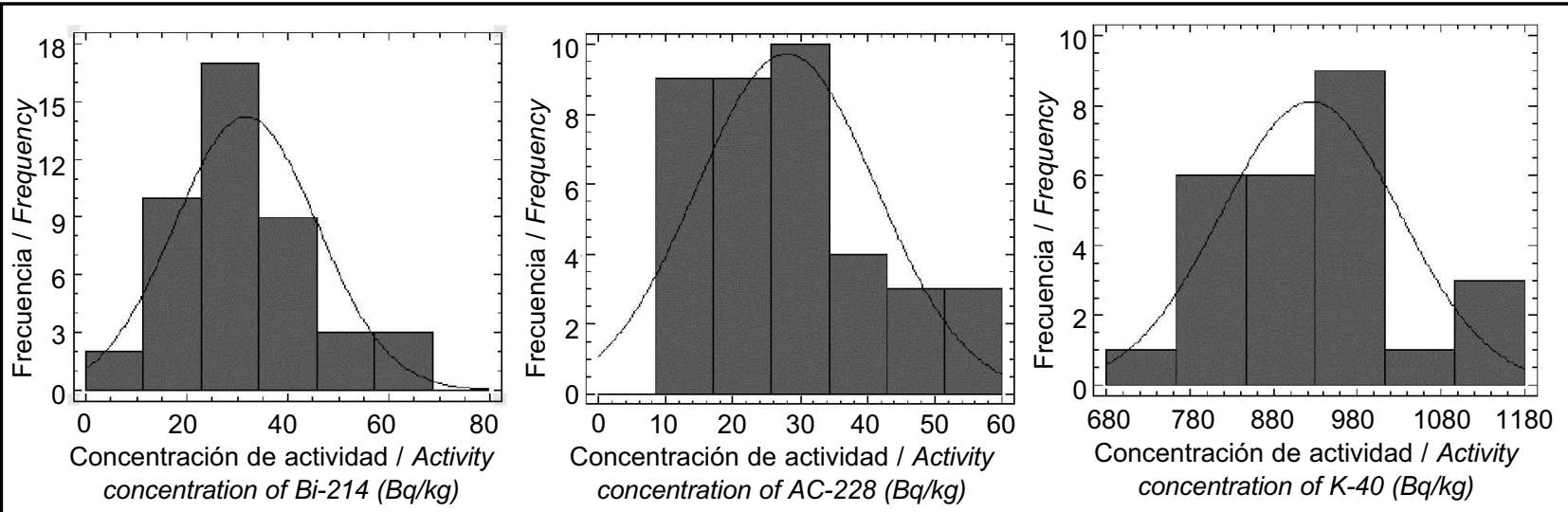

Figura 3. Distribuciones de probabilidad de ${ }^{214} \mathrm{Bi}\left({ }^{226} \mathrm{Ra}\right),{ }^{228} \mathrm{Ac}\left({ }^{232} \mathrm{Th}\right)$ y ${ }^{40} \mathrm{~K}$ en las muestras de mortero de cemento. Figure 3. Frequency distributions of ${ }^{214} \mathrm{Bi}\left({ }^{226} \mathrm{Ra}\right),{ }^{228} \mathrm{AC}(232 \mathrm{Th})$ and ${ }^{40} \mathrm{~K}$ in cement mortar samples. 
El contenido de radiactividad natural determinado en el PG, materias primas y cemento modificado se muestra en la Tabla 5. Los valores del índice de concentración de actividad I, se incluyen también en la misma Tabla. Por una parte, estos resultados indican que la concentración de actividad de los radionucleidos de origen natural en las muestras de PG usadas en nuestros estudios es menor a los observados en muestras de fosfoyeso procedentes de otros países $(18,25,26)$. Por otra parte, se observa un descenso proporcional del contenido radiactivo en el cemento modificado en comparación con las muestras originales de PG, a excepción de los niveles de ${ }^{40} \mathrm{~K}$ y ${ }^{232} \mathrm{Th}$.
The natural radioactivity content determined in $P G$, raw materials and the modified cement samples is shown in Table 5. The activity concentration index, $I$, is also reported in the same Table. On one hand, these results indicate that the activity concentration of naturallyoccurring radionuclides in the $P G$ samples used for our study is lower than that observed in samples coming from other countries $(18,25,26)$. On the other hand, a proportional decrease of the natural radioactive content in the modified cement is observed in comparison with the initial PG sample values. However, an exception was observed for ${ }^{40} \mathrm{~K}$ and $232 \mathrm{Th}$ levels. The content of

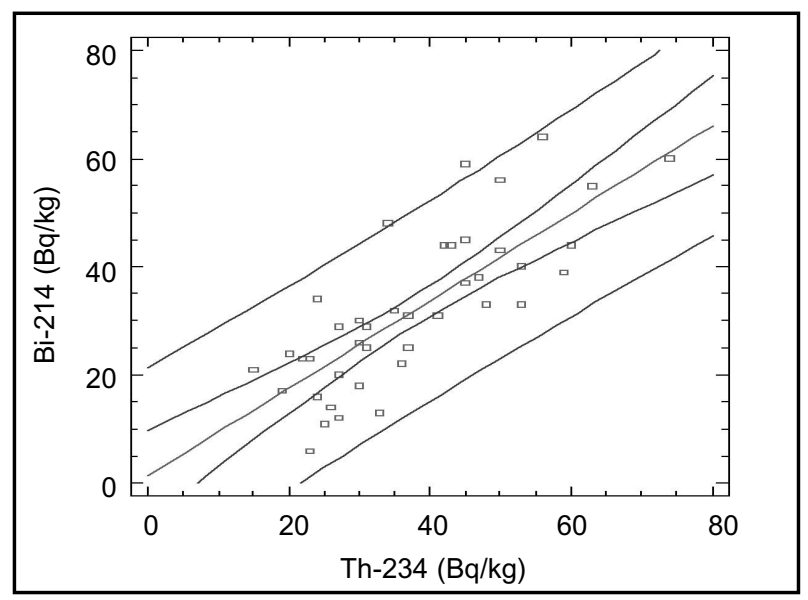

Figura 4. Relación 214Bi/234Th en muestras blanco de mortero de cemento. La relación 1 implica equilibrio radioactivo. Figure 4. ${ }^{214} \mathrm{Bi} / 234$ Th ratio in blank cement mortar samples. Ratio 1 implies the radioactive equilibrium.

Tabla 5 / Table 5

Valores de concentración de actividad de radionucleidos naturales de la serie del ${ }^{238 \mathrm{U}}\left({ }^{226} \mathrm{Ra},{ }^{210} \mathrm{~Pb}\right.$ y ${ }^{210} \mathrm{Po}$ en equilibrio radioactivo en este estudio), ${ }^{232} \mathrm{Th}$ y ${ }^{40} \mathrm{~K}$, expresados en $\mathrm{Bq} \cdot \mathrm{kg}^{-1}(\mathrm{k}=2)$ y del índice de concentración de actividad (I) para los diferentes materiales estudiados.

Values of natural radionuclides activity concentration from 238 Useries $(226 \mathrm{Ra}, 210 \mathrm{~Pb}$ and $210 \mathrm{Po}$ in radioactive equilibrium in this experiment), ${ }^{232} \mathrm{Th}$ and ${ }^{40} \mathrm{~K}$ expressed in $\mathrm{Bq} \cdot \mathrm{kg}^{-1}(\mathrm{k}=2)$ and activity concentration index, $\mathrm{I}$, for the different studied materials.

\begin{tabular}{|c|c|c|c|c|c|c|c|}
\hline \multirow{2}{*}{\multicolumn{2}{|c|}{ Muestra / Sample }} & \multicolumn{6}{|c|}{ Concentración de actividad $\left(\mathrm{Bq} \cdot \mathrm{kg}^{-1}\right) \pm \mathrm{DE} /$ Activity concentration $\left(\mathrm{Bq} \cdot \mathrm{kg}^{-1}\right) \pm S D$} \\
\hline & & \multirow{2}{*}{$\begin{array}{c}{ }^{226} \mathbf{R a}\left({ }^{214} \mathrm{Bi}\right) \\
0.27 \pm 0.17< \\
(0.40)^{* *}\end{array}$} & \multirow{2}{*}{$\frac{210 \mathbf{P b}^{\star \star}}{-}$} & \multirow{2}{*}{$\frac{{ }^{210} \mathrm{Po}}{<(10)^{* *}}$} & \multirow{2}{*}{$\frac{{ }^{40} \mathrm{~K}}{-}$} & \multirow{2}{*}{$\frac{{ }^{232} \mathrm{Th}\left({ }^{228} \mathrm{Ac}\right)}{<(0.69)^{* *}}$} & \multirow{2}{*}{$\frac{\text { I }}{0.01}$} \\
\hline \multirow{3}{*}{$\begin{array}{l}\text { Materia prima / } \\
\text { Raw Materiales }\end{array}$} & $\begin{array}{l}\text { Polímero / } \\
\text { Polymer }\end{array}$ & & & & & & \\
\hline & Azufre / Sulphur & $\begin{array}{c}0.44 \pm 0.22< \\
(0.50)^{* *}\end{array}$ & - & $<(12)^{* *}$ & - & $<(0.82)^{* *}$ & 0.01 \\
\hline & Arena / Sand & $12.3 \pm 0.90$ & - & $<(26)^{* *}$ & $674 \pm 30$ & $14.8 \pm 1.8$ & 0.34 \\
\hline $\begin{array}{c}\text { Fosfoyeso / } \\
\text { Phosphogypsum }\end{array}$ & PG & $205 \pm 8$ & $161 \pm 66$ & $214 \pm 90$ & $<14$ & $18.6 \pm 1.4$ & 0.78 \\
\hline \multirow{2}{*}{$\begin{array}{c}\text { Cemento } \\
\text { modificado / } \\
\text { Modified Cement }\end{array}$} & SPC-PG15 & $26.5 \pm 2.2$ & $34 \pm 16(36)$ & $25 \pm 11$ & $613 \pm 32$ & $13.3 \pm 2.9$ & 0.42 \\
\hline & SPC-PG17 & $27.1 \pm 2.2$ & $23 \pm 26(56)$ & $21 \pm 10$ & $730 \pm 180$ & $16.9 \pm 2.7$ & 0.36 \\
\hline \multirow{2}{*}{$\begin{array}{c}\text { Materiales de } \\
\text { construcción } \\
\text { utilizados } \\
\text { comúnmente en } \\
\text { España / Common } \\
\text { Spanish building } \\
\text { materilas }\end{array}$} & $\begin{array}{c}\text { Mortero de } \\
\text { Cemento / } \\
\text { Cement mortar }\end{array}$ & $32 \pm 14$ & - & - & $924 \pm 107$ & $28 \pm 13$ & $0.55 \pm 0.37$ \\
\hline & Ladrillo / Bricks & $88 \pm 34$ & - & - & $1000 \pm 133$ & $74 \pm 35$ & $1.00 \pm 0.60$ \\
\hline
\end{tabular}

DE: Desviación Estándar, **LD: Limité de Detección (entre paréntesis) / SD: Standard Deviation, **LD: Detection Limit (in brackets). 
El contenido de estos radionucleidos naturales en la arena, frecuentemente usada como materia prima en la industria del cemento, es normalmente más elevado que el determinado en suelos u otros materiales, lo que explicaría el incremento de la concentración de actividad de estos dos radionucleidos en el producto final, siendo incluso más relevante que el observado en el PG inicial. En el caso de la concentración de actividad del ${ }^{226} \mathrm{Ra}$, los resultados obtenidos para el cemento modificado (26-27 $\mathrm{Bq} \cdot \mathrm{kg}^{-1}$ ) (Tabla 5) son similares a los valores medios correspondientes a las muestras blanco de morteros analizadas (37 Bq. $\mathrm{kg}^{-1}$, ver Figura 3).

Los valores obtenidos del índice de concentración de actividad (I) en el cemento modificado, son menores que los límites sugeridos por la Comisión Europea (20). Además, estos valores son incluso inferiores a los calculados para las muestras blanco de ladrillos, debido al elevado contenido de ${ }^{40} \mathrm{~K}$ en este tipo de material, lo cuál avalaría el uso de cemento modificado como material de construcción. No obstante, desde un punto de vista radiactivo su uso debería ser permitido por la legislación vigente (27-29). El principal inconveniente en el empleo del cemento modificado estaría asociado con su producción a escala industrial. La volatilización del $210 \mathrm{Po}$, si se alcanzan altas temperaturas en la producción del cemento, o las emanaciones del radon podrían afectar a los trabajadores que manipulen el PG directamente o realicen sus tareas en áreas de la fábrica donde serían probables emisiones de radón (30). La toxicidad de otros elementos químicos existentes en el PG, las dificultades que presentaría su almacenamiento cerca de las cementeras y el establecimiento de un cierto nivel de control en las diferentes etapas de producción del cemento modificado constituyen las desventajas más significativas a considerar para el desarrollo de esta aplicación a una mayor escala.

\section{CONCLUSIONES}

Los estrictos estándares para el vertido directo del PG en balsas hacen necesaria la investigación de las posibilidades de su re-utilización a través de uso comercial y en ingeniería civil, con el fin de resolver el problema ambiental originado por su almacenamiento. No obstante, y teniendo presente los problemas ambientales referentes a la exposición radiactiva producida por el PG, su utilización para la obtención de materiales de construcción debe realizarse respetando la legislación y normativa vigentes en relación a los valores límite recomendados de radionucleidos naturales en este tipo de materiales.

Los resultados indican que el cemento modificado obtenido a partir de PG presenta menor nivel de concentración de radionucleidos naturales que el PG original, debido these two naturally-occurring radionuclides in sand frequently used in the cement industry- is usually higher than that determined in soils and other common natural materials, which can explain the increment of the natural radioactivity content of the final product, being even more relevant than the one observed in the initial $P G$. In the case of ${ }^{226} R a$ activity concentration and in comparison with the average values obtained for the blank cement mortar samples (37 Bq. $\mathrm{kg}^{-1}$, see Figure 3), quite similar values were obtained for the modified cement (26-27 Bq. $\mathrm{kg}^{-1}$ ) (Table 5).

The values obtained for the activity concentration index, $I$, of the modified cement are below the limits suggested by the European Commission (20). Furthermore, these values are even lower than those calculated for the blank bricks samples, due to the higher content of $40 \mathrm{~K}$ in bricks, which could support the use of the modified cement as building material. However and from a radiological point of view, this use should be allowed by governing law (27-29). The main inconvenience of employing this modified cement would probably be associated with its production at industrial scale. The 210 Po volatilization -if high temperatures are reached in the cement production- or the radon emanation could affect the workers who manipulate $P G$ directly or realize their tasks in areas where these emissions are probable (30). The toxicity of other chemical elements existing in $P G$, the difficulties that would present its storage close to the cement industries and a certain control in the different production stages should be also considered as disadvantages for its use.

\section{CONCLUSIONS}

The stricter environmental standards on land PG disposal make necessary the research on solving the environmental problem of the PG stacks, by finding commercial and civil engineering uses, However and in view of the environmental problems related to the radiation exposure from the $P G$, the legislations and standard regulations on the limit levels of the natural radionuclides content must be respected and taken into account when $P G$ is used for making construction materials.

Results indicate that the modified cement manufactured by using $P G$ shows lower radionuclides concentration values than those of the initial PG. Also, when compared 
principalmente al efecto de dilución con otros materiales. Adicionalmente, cuando se comparan estos resultados con el contenido de radionucleidos naturales en diversos materiales de construcción españoles de uso habitual, se comprueba que los valores son similares, lo que indica que este material modificado cumpliría el límite de exención europeo recomendado para la exposición a la radiación gamma externa. Este hecho avalaría su uso como material de construcción, siendo el proceso de estabilización/solidificación descrito en este trabajo una alternativa adecuada y eficaz para el tratamiento del PG.

\section{AGRADECIMIENTOS}

Los autores quieren manifestar su agradecimiento al Plan de Nacional de I+D+I (Proyecto CTQ200802012/PPQ) por la financiación de este estudio. Se quiere agradecer también a M. Sánchez Sánchez del Departamento de Tecnología del CIEMAT por la ayuda en el análisis de uranio mediante la técnica de fosforimetría láser. Finalmente, Hanan Tayibi agradece al CSIC el contrato I3P (I3PDR-6-01) que le ha permitido desarrollar estas investigaciones. to some common Spanish building materials, similar values are obtained, which indicates that this material fulfils European recommended exception limit for exposure to external gamma radiation. This finding could make possible its use as building material. Thus the $S / S$ process developed in this work could be considered as a suitable and efficient option for PG treatment.

\section{ACKNOWLEDGEMENTS}

The authors are grateful to the Spanish National R\&D\&I Plan (Project CTQ2008-02012/PPQ) for the financial support of this study. We also thank M. Sánchez Sánchez from Technology Department of CIEMAT for his help in the uranium analysis. Finally, Hanan Tayibi is grateful to CSIC for an I3P contract (I3PDR-6-01).

\section{BIBLIOGRAFÍA / BIBLIOGRAPHY}

(1) Yang, J.; Liu, W.; Zhang, L.; Xiao B.: "Preparation of load-bearing building materials from autoclaved phosphogypsum". Const. Build. Mat. 23 (2009), pp. 687-693. doi:10.1016/j.conbuildmat.2008.02.011

(2) Tayibi, H.; Choura, M.; López, F. A.; Alguacil, J. A.; López-Delgado, A.: "Environmental impact and management of phosphogypsum (Review)". J. Environ. Manage. 90 (2009), pp. 2377-2386. doi:10.1016/j.jenvman.2009.03.007 PMid:19406560

(3) Soil amendments and Environmental Quality. Aquiculture and Environmental Series. Ed. By Jack, E. Rechcigl. Boca Raton, Lewis Publishers (CRC Press), Florida (1995), pp. 504.

(4) Rutherford, P. M.; Dudas, M. J.; Samek, R. A.: "Environmental impacts of phosphogypsum". Sci. Total Environ. 149 (1-2) (1994), pp. 1-38. doi:10.1016/0048-9697(94)90002-7

(5) Kovler, K.: "Radiological constraints of using building materials and industrial by-products". Const. Build. Mat. 23 (2009), pp. 246253. doi:10.1016/j.conbuildmat.2007.12.010

(6) Bolivar, J. P.; García-Tenorio, R.; Vaca, F.: "Radioecological study of an estuarine system located in the south of Spain". Water Research 34 (2000), pp. 2941-2950. doi:10.1016/S0043-1354(99)00370-X

(7) US-EPA. U. S. Environmental Protection Agency, 2002. "National Emission Standards for Hazardous Air Pollutants, Subpart R" (2002).

(8) Min, Y.; Jueshi, Q.; Ying, P.: "Activation of fly ash-lime systems using calcined phosphogypsum". Const. Build. Mat. 22 (2008), pp. 1004-1008. doi:10.1016/j.conbuildmat.2006.12.005

(9) Weiguo, S.; Mingkai, Z.; Qinglin, Z.: "Study on lime-fly ash-phosphogypsum binder". Const. Build. Mat. 21 (7) (2007), pp. 14801485.

(10) Degirmenci, N.: "Utilisation of phosphogypsum as raw and calcined material in manufacturing of building products". Const. Build. Mat. 22 (2008), pp. 1857-1862. doi:10.1016/j.conbuildmat.2007.04.024

(11) Yang, M.; Qian, J.; Pang, Y.: "Activation of fly ash-lime systems using calcined phosphogypsum". Const. Build. Mat. 22 (2008), pp. 1004-1008. doi:10.1016/j.conbuildmat.2006.12.005

(12) Taher, M. A.: "Influence of thermally treated phosphogypsum on the properties of Portland slag cement". Resour. Conserv. Recycl. 52 (1) (2007), pp. 28-38. doi:10.1016/j.resconrec.2007.01.008

(13) Elkhadiri, I.; Diouri, A.; Boukhari, A.; Puertas, F.; Vázquez, T.: "Obtaining a sulfoaluminate belite cement by industrial wastes". Mater. Construcc. 270 (5) (2003), pp. 57-69.

(14) NRCP Report 094. Exposure of the Population in the United States and Canada from Natural Background Radiation, (1987).

(15) US-EPA. "Potential uses of Phosphogypsum and associated risks: Background information document". EPA 402-r92-002. US-EPA, Washington, DC (1992). 
(16) Mas, J. L.; San Miguel, E. G.; Bolívar, J. P.; Vaca F.; Pérez-Moreno J. P.: "An assay on the effect of preliminary restoration tasks applied to a large TENORM wastes disposal in the south-west of Spain". Sci. Total Environ. 364 (2006), pp. 55-66. doi:10.1016/j.scitotenv.2005.11.006 PMid:16343599

(17) Burnett, W. C.; Schultz, M. K.; Carter, D. H.: "Radionuclide flow during the conversion of phosphogypsum to ammonium sulfate". J. Environ Radioact. 32 (1-2) (1996), pp. 33-51. doi:10.1016/0265-931X(95)00078-O

(18) El Afifi, E. M.; Hilal, M. A.; Attallah, M. F.; El-Reefy, S. A.: "Characterization of phosphogypsum wastes associated with phosphoric acid and fertilizers production". J. Environ Radioact. 100 (2009), pp. 407-412. doi:10.1016/j.jenvrad.2009.01.005 PMid:19272681

(19) Soil amendments and Environmental Quality. Agriculture and Environmental Series. Ed. By Jack, E. Rechcigl. Boca Raton, Lewis Publishers (CRC Press), Florida, (1995), pp. 504.

(20) Radiological Protection Principles concerning the Natural Radioactivity of Building Materials. Radiation Protection 112, European Commission. Directorate-General Environment, Nuclear Safety and Civil Protection (1999).

(21) Vroom, A. H.: "Sulfur polymer concrete and its applications". In: Proceedings of Seventh International Congress on Polymers in Concrete. Moscow, September (1992), pp. 606-621.

(22) López, F. A.; Gázquez, M.; Alguacil, F. J.; Bolívar, J. P; García-Díez, I.: "Microencapsulation of phosphogypsum into a sulfur polymer matrix: Physico-chemical and radiological characterization". J. Hazard. Mater., 19 (2011), pp. 234-245.doi: 10.1016/j.jhazmat.2011.05.010.

(23) Norma Española UNE 102031; Yesos y escayolas de construcción, Métodos de ensayo físicos y mecánicos, Sep. (1999).

(24) Flynn, W. W.: "The determination of low level of polonium-210 in environmental materials". Analytica Chimica Acta 43 (1968), pp. 221-227. doi:10.1016/S0003-2670(00)89210-7

(25) Mazzilli, B.; Saueia, C.: "Radiological Implications of Using Phosphogypsum as a building material in Brazil". Radiation Protection Dosimetry, Technical Note. 86 (1) (1999), pp. 63-67.

(26) Hull, C. D.; Burnett, W. C.: "Radiochemistry of Florida phosphogypsum". J. Environ. Radioact. 32 (1996), pp. $213-238$. doi:10.1016/0265-931X(95)00061-E

(27) The Commission of the European Communities. Commission Recommendation of 21 February 1990 on the protection of the public against indoor exposure to radon 90/143/EURATOM. Official Journal L-80 (1990).

(28) The Council of European Communities. Council Directive 89/106/EEC of 21 December 1988 on the approximation of laws, regulations and administrative provisions of the Member States relating to construction products. Official Journal L-040 (1989).

(29) International Commission on Radiological Protection. Protection against Radon222 at Home and at Work. ICRP Publication 65 (Oxford: Pergamon Press) (1994).

(30) IAEA-TECDOC-1472.: "Naturally Occurring Radioactive Materials (NORM IV)". Proceedings of an international conference held in Szczyrk, Poland, 17-21 May, (2004). 